\title{
アンサンブル実験による全球陸域 積雪シミュレーションの不確実性評価 ENSEMBLE EXPERIMENTS TO QUANTIFY UNCERTAINTY IN GLOBAL SNOW SIMULATION
}

\author{
新田友子 1 ・芳村圭 2 ・ James D Annan ${ }^{3}$ ・ Julia C Hargreaves ${ }^{4}$ ・鼎信次郎 5 ・沖大幹 6 \\ Tomoko NITTA, Kei YOSHIMURA, James D ANNAN, Julia C HARGREAVES, \\ Shinjiro KANAE and Taikan OKI \\ 1学生会員 工修 東京大学 大学院工学系研究科（干153-8505 東京都目黒区駒場4-6-1） \\ 2正会員 工博 東京大学 大気海洋研究所（干277-8564 千葉県柏市柏の葉5-1-5） \\ ${ }^{3}$ Non-Member of JSCE, Ph.D., Research Institute for Global Change, JAMSTEC \\ ${ }^{4}$ Non-Member of JSCE, Ph.D., Research Institute for Global Change, JAMSTEC \\ 5 正会員 工博 東京工業大学 大学院情報理工学研究科（干152-8552 目黒区大岡山2-12-1） \\ 6正会員 工博 東京大学 生産技術研究所（干153-8505 東京都目黒区駒場4-6-1）
}

\begin{abstract}
Global- and continental-scale snow simulation has been used to produce snow estimates and attribute the change of snow into hydrological variables. However, uncertainties in global- and continental-scale snow simulation due to model structure, model parameters, and meteorological forcing has not been well documented. In the present study, we used MATSIRO land surface model and conducted ensemble simulations for snow, i.e., perturbed parameter ensemble simulation and multi precipitation ensemble simulation. The results show that uncertainties in parameters are larger in the melting season than accumulation season and uncertainties in precipitation are large in accumulation seasons. The uncertainties of parameters in melting season are comparable to that of precipitation.
\end{abstract}

Key Words : snow, land surface model, uncertainty analysis

\section{1. はじめに}

積雪被覆は世界の多くの場所で特に春・夏季に減少し ていると報告されている(1)2)。大陸・全球スケールの積 雪変化とその原因を明らかにするにあたって, 衛星観測 から得られる積雪に関する物理量は限られるため, また 高緯度域は現地観測の少ない場所を含むため，モデルの 利用が有用な手法のひとつとなる．例えば，Liston and $\mathrm{Hiemstra}^{3)}$ は，再解析データを10 kmの空間解像度にダ ウンスケーリングし，雪モデルを用いて北極圈における 1979年から2009年の積雪トレンドについて調べている. その結果，北極圏の積雪は全体としては減少傾向にある ものの，地域的な変化が大きく，北極圈全域にわたって 減少傾向の場所と増加傾向の場所が存在することを示し ている.また，Shi et al. ${ }^{4)}$ はVICモデルを用いて衛星 によって観測された北半球の積雪被覆変化を再現し, 熱 収支のどの要素が積雪被覆変化に影響を与えているのか
を調べ，積雪被覆変化には正味放射変化の影響が最も大 きく, 次に顕熱変化の影響が大きいことを示している. このような積雪の変化を検出し原因を特定する研究は大 変興味深いが，モデルの出力值には，モデル構造，パラ メータ, 気象強制力に起因する不確実性があり，ひとつ のシミュレーション結果が必ずしも正しいとは言えない.

ここでの不確実性とは，ランダムノイズに起因する統 計的な不確実性ではなく, データを作成する際の, つま りシミュレーションを行って結果を出力する過程におけ る不確実性を意味している. モデル構造の不確実性は, 同じ変数をシミュレーションするとき, モデルとそのス キームの選択肢が複数あることから，それら全ての出力 值のばらつきで表現できる，パラメータの不確実性は， いったんモデルを選択するとモデルが持つパラメータの 值は限られた数のデータから決めなければならないため, また全球パラメータの場合は実際には条件によって異な る值をとることがあるために生じる. 気象強制力（モデ ルに与える降水量, 放射量, 気温等）の不確実性は, 全 


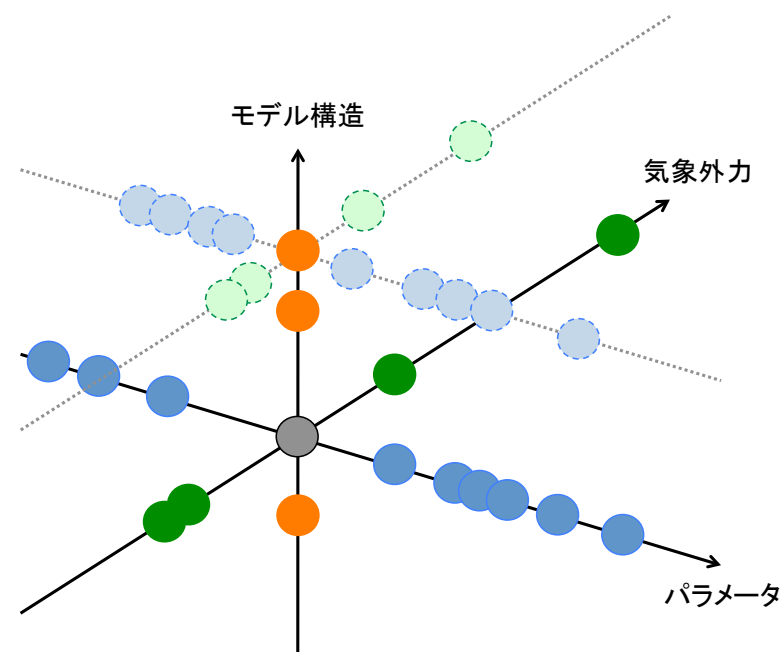

図-1アンサンブル実験による不確実性評価の概念図.

ての場所と時間の連続的な観測は不可能で，観測プロダ クトによって特徵が異なる可能性があるために生じる.

つまり図-1のように，モデル構造，気象外力，パラメー タの 3 つの軸に関して不確実性が存在すると考えられる. このような不確実性が存在するため, モデルの出力值を 用いる場合には，限られたデータを有効に利用して検証 を行うこと，シミュレーションの不確実性を定量的に評 価することが重要な課題である．また，モデルの不確実 性評価は将来的に観測データをモデルに同化する場合に も重要な情報となる.

モデル構造の改良点と不確実性を明らかにするために, モデルを相互に比較し検証する研究が行われている56).

また，雪モデルのパラメータ不確実性評価 ${ }^{7) 8)}$ も行われて いる. しかしながら，このような研究は，ある特定の場 所や流域を対象とする場合が多く，大陸・全球スケール で積雪シミュレーションの不確実性を評価する研究は, あまり行われてこなかった。

そこで本研究では，全球積雪シミュレーションの不確 実性評価を行う。近年気候変動予測の分野では, アンサ ンブル実験を用いた不確実性評価が行われている910).

この手法を参考にして，いつ，どこで，どのくらい，積 雪水当量の計算結果に全球パラメータと気象強制力に起 因する不確実性があるのかを検討することを目的とする。 パラメータの不確実性に関しては，年平均積雪面積を用 いて制約を行う。これは，精度よい衛星観測が得られる 積雪被覆率から計算できるためである。 また, 年平均積 雪面積を用いて制約した場合に，積雪被覆率に対して感 度のあるチューニングパラメータを持つモデルと持たな いモデルで，積雪水当量のパラメータ不確実性がどのよ うに変化するのかについても検討を行う，以下では，第 2章(1)で用いたモデルと標準実験の設定を説明し，（2） でパラメータ，(3) で気象強制力の不確実性を定量化す るためのアンサンブル実験の設定を説明する. (4)では モデル間の比較をどのように行ったかについて説明する. 第3章で結果を示し，第4章でまとめを述べる.
表-1 パラメータ摂動アンサンブル実験に用いたパラメータ

\begin{tabular}{lllll}
\hline パラメータ & & 標準 & 最小 & 最大 \\
\hline \hline 被覆率 1 になる閾值 & $\mathrm{P} 1$ & $120 \mathrm{~kg} / \mathrm{m}^{2}$ & $1 \times 10^{-20}$ & 150 \\
積雪の熱伝導率 & $\mathrm{P} 3$ & $0.3 \mathrm{~W} / \mathrm{K} / \mathrm{m}$ & 0.05 & 0.7 \\
積雪密度 & $\mathrm{P} 4$ & $300 \mathrm{~kg} / \mathrm{m}^{3}$ & 50 & 600 \\
最大凍結率 & $\mathrm{P} 5$ & 0.1 & 0 & 0.5 \\
新雪アルベド (可視) & $\mathrm{P} 7$ & 0.9 & 0.7 & 0.999 \\
新雪アルベド (近赤外) & $\mathrm{P} 8$ & 0.7 & 0.4 & 0.8 \\
古い雪のアルベド (可視) & $\mathrm{P} 9$ & 0.4 & 0.3 & 0.7 \\
古い雪のアルベド (近赤外) P10 & 0.2 & 0.1 & 0.5 \\
Refreshに必要な積雪量 & $\mathrm{P} 11$ & $1 \mathrm{~kg} / \mathrm{m}^{2}$ & 0.1 & 20 \\
Aging の温度依存の係数 & $\mathrm{P} 12$ & $5000 \mathrm{~K}$ & 500 & 50000 \\
古さの関数の時定数 & $\mathrm{P} 13$ & $2 \times 10^{6} \mathrm{~s}$ & $2 \times 10^{5}$ & $2 \times 10^{7}$ \\
污れ係数 (切片) & $\mathrm{P} 14$ & 0.01 & 0.001 & 0.1 \\
污れ係数 (傾き) & $\mathrm{P} 15$ & 0.1 & 0.01 & 0.3 \\
污れ係数 (最大值) & $\mathrm{P} 16$ & 1 & 0.5 & 50 \\
積雪面の粗度 (運動量) & $\mathrm{P} 18$ & $0.05 \mathrm{~m}$ & 0.001 & 0.1 \\
積雪面の粗度 (熱) & $\mathrm{P} 19$ & $0.001 \mathrm{~m}$ & 0.0001 & 0.01 \\
\hline
\end{tabular}

\section{2. 手法}

\section{（1）モデルと実験設定}

積雪シミュレーションには陸面モデルMATSIRO ${ }^{11)}$ を 用いる. MATSIROは気候モデルの下部境界条件として 重要な地表面からのエネルギー・水フラックスを表現す る目的で開発されたモデルである. 大気海洋結合モデル MIROC5に合わせて改良されたMATSIROは，6層14mの 土壌層, 最大3層の積雪層, 1層のキャノピー層で, 陸面 の温度と水の量を予報する. 積雪水当量の時間変化は,

$\frac{d S_{n}}{d t}=P_{s n}^{*}-E_{s}^{(s n)}-M_{s n}+F_{R}$

から計算する.ただし， $S_{n}$ : グリッド平均の積雪水当量, $P_{s n}^{*}$ : キャノピーによる遮断後の降雪量, $E_{s}^{(s n)}$ : 昇華量, $M_{s n}$ : 融雪量, $F_{R}$ : 融雪水及び降雨の再凍結量である.

積雪温度は以下の熱伝導方程式から計算する.

$c_{i} \frac{d T_{s n}}{d t}=\frac{\partial}{\partial z} k_{s n} \frac{\partial T_{s n}}{\partial z}$

ただし,$c_{i}$ : 積雪の熱容量, $T_{s n}$ : 積雪温度, $k_{s n}$ : 積雪の 熱伝導率, $z$ : 積雪深とする. $T_{s n}$ が融点より高くなった 場合には， $T_{s n}$ を $0{ }^{\circ} \mathrm{C}$ 固定し，融雪量を計算する．積雪 アルベドは，ダストと黒色炭素の沈着による污れの影響 を考慮した積雪古さの関数を用いて計算する.

標準実験は全球 1 度の空間解像度, 1時間のタイムス テップで行った。 また，気象強制力として再解析と観測 降水量を組み合わせて作成されたデータ ${ }^{12)}$ を用いた. 実験は標準実験の2000年1月 1 日 0 時を初期值として, 2000年から2007年まで実験を行い，2000年はスピンアッ プとして除外し，2001年から2007年までの7年間の結果 を用いた。 

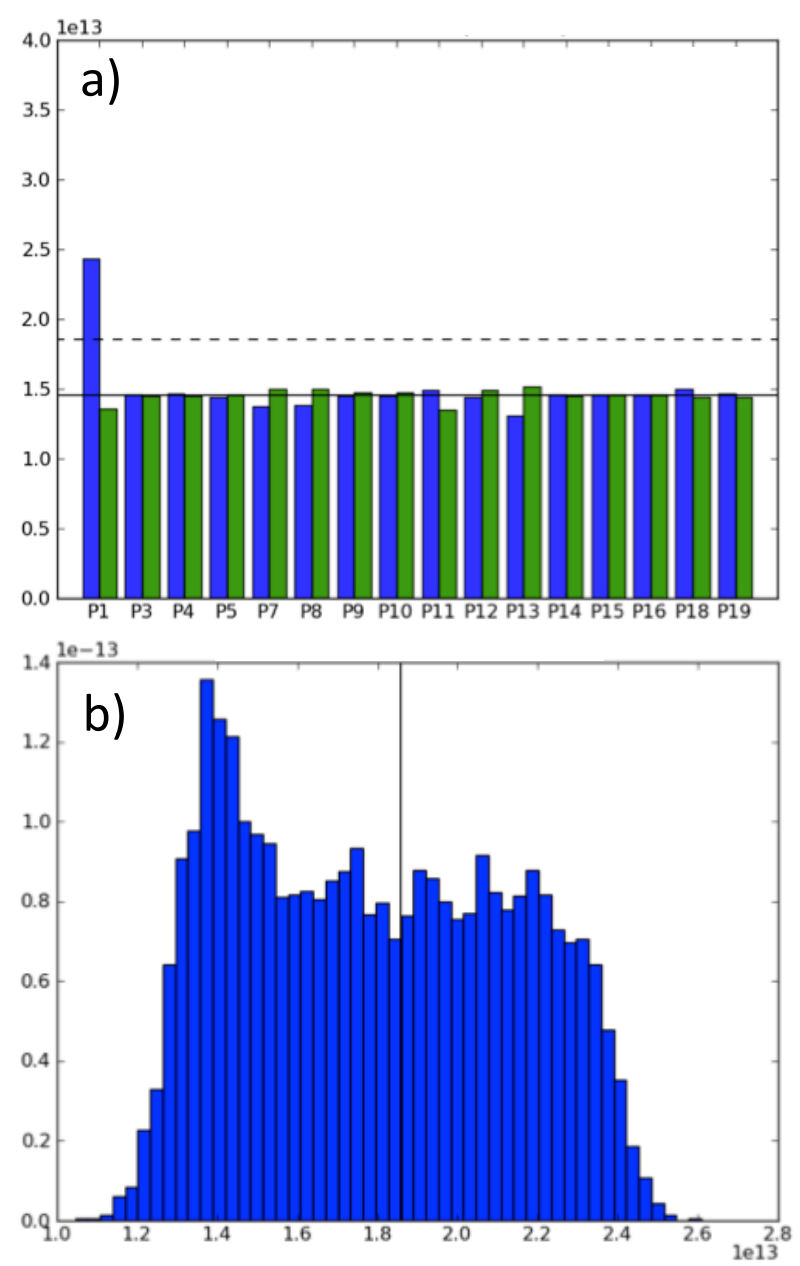

図-2 パラメータ摂動実験におけるパラメータの選択手法. a) 各パラメータを最大値と最小值に摂動させた場合の北半球年平 均積雪面積. 横軸が各パラメータ, 縦軸が北半球年平均積雪面 積 $\left[\mathrm{m}^{2}\right]$ で，青と緑の棒グラフがそれぞれ最小值と最大值にした 場合の結果, 黒実線が標準実験の結果, 黒点線が観測値. b) 10000 のパラメータセットに対して、線形的に計算した積雪 面積のヒストグラム．黒実線は観測．横軸が北半球年平均積雪 面積 $\left[\mathrm{m}^{2}\right]$, 縦軸は確率.

\section{（2）パラメータ摂動アンサンブル実験}

パラメータの不確実性を定量化するために，異なるパ ラメータの值を用いた感度実験を行う。パラメータには, 全球パラメータと土地利用ごとや土壤タイプごとに異な る值をとるパラメータがあるが，ここでは全球パラメー タのみに着目する．積雪水当量に及ぼす影響が大きいと 予想されるパラメータを16個選択した。表-1に選択した パラメータとその標準值，最小值と最大值を示す．地点 シミュレーションにおけるパラメータの不確実性を評価 した既往研究では，数千のオーダーのパラメータセット を作成し，再現性の良い結果のみを選択して解析すると いう手法をとっているが，全球シミュレーションでは計 算負荷が大きすぎて困難であるため，観測に近い結果が 期待できるパラメータセットを最初に選択する.まず, 各パラメータを最小值と最大值に振って残りのパラメー タに標準值を与えた実験を行った．図-2のa)に，この実 験結果から7年間平均の北半球積雪面積を計算した結果 を示す. 次に, Latin Hypercube Sampling ${ }^{13)}$ (LHS) を用 いて，表-1に示した全てのパラメータの值を同時に変え た10000のパラメータセットを作成した．LHSで作成し た各パラメータの值に対して，パラメータを最小值と最 大值に摂動させた結果（図-2a）を用いて，線形補間し て北半球積雪面積を計算した．結果のヒストグラムを図 -2 b)に示す。黒の縦線は観測值で, MODISの積雪被覆率 14)から計算した. ここから, 観測值と近い30のパラメー タセットを取り出した. この值を用いて，30メンバーで 2000年から2007年までのアンサンブル実験を行った.

\section{（3）気象強制カのアンサンブル実験}

オフライン実験による全球積雪シミュレーションには, 気象強制力に関する不確実性も大きいと予想される. 本 研究では，気象強制力の中でも積雪に影響が大きいと予 想される降水量の夕に着目して, Kim et al. ${ }^{12)}$ の5種類の データセットを用いて降水量に起因する不確実性を見積 もつた。つまり，5メンバーで2000年から2007年までの アンサンブル実験を行った.

\section{(4) モデル間の比較}

簡単なモデルとして，アルベドを時定数のみで低減さ せ，積雪被覆率を $0 / 1$ で表現し，液体水の再凍結を考慮 しないモデルを作成した（モデルA）。また，上記（2） と（3）のアンサンブル実験に用いた標準のMATSIR0をモ デルBとした. 複雑なモデルとして, 積雪被覆率算定ス キームとしてSSNOWD ${ }^{14)}$ を用い，積雪密度を予報し熱伝導 率を診断し, 液体水の貯留を考え, 標高帯によるモザイ ク考慮したモデルを作成した（モデルC）。モデルAには アルベド低減の時定数を追加し，標準で $2 \times 10^{6} \mathrm{~s}$ ，最小 值が $2 \times 10^{5} \mathrm{~s}$ ，最大值が $2 \times 10^{7} \mathrm{~s}$ とした。 またモデルCに は液体水の最大貯水量（標準0.05, 最小值0, 最大值 $0.5 ）$, 雨雪判別に用いる湿球温度（標準 $0^{\circ} \mathrm{C}$, 最小值 -

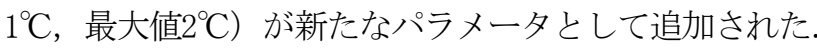
つまり，モデルBは積雪被覆に対して感度のあるチュー ニングパラメータ（表1のP1）を持つモデルであるのに 対して，モデルAとモデルCは，感度のあるチューニング パラメータを持たないモデルとなる.それぞれのモデル に対して（2）と同じ手順を踏んで実験を行う。ただし， モデルAは積雪面積を過大評価するという系統的なバイ アスを持ち，図-2 b) のヒストグラムを描くと，観測よ りもヒストグラムの最小值が大きくなる，それによって 偏ったパラメータを選択して，不確実性が過小に評価さ れる可能性がある. そのため, 全てのモデルに関してヒ ストグラムの中央值を観測と仮定して（つまりバイアス のない条件を仮定して），モデル間の比較を行った。つ まり，モデル間の比較に関しては，モデルA，B，Cを用 

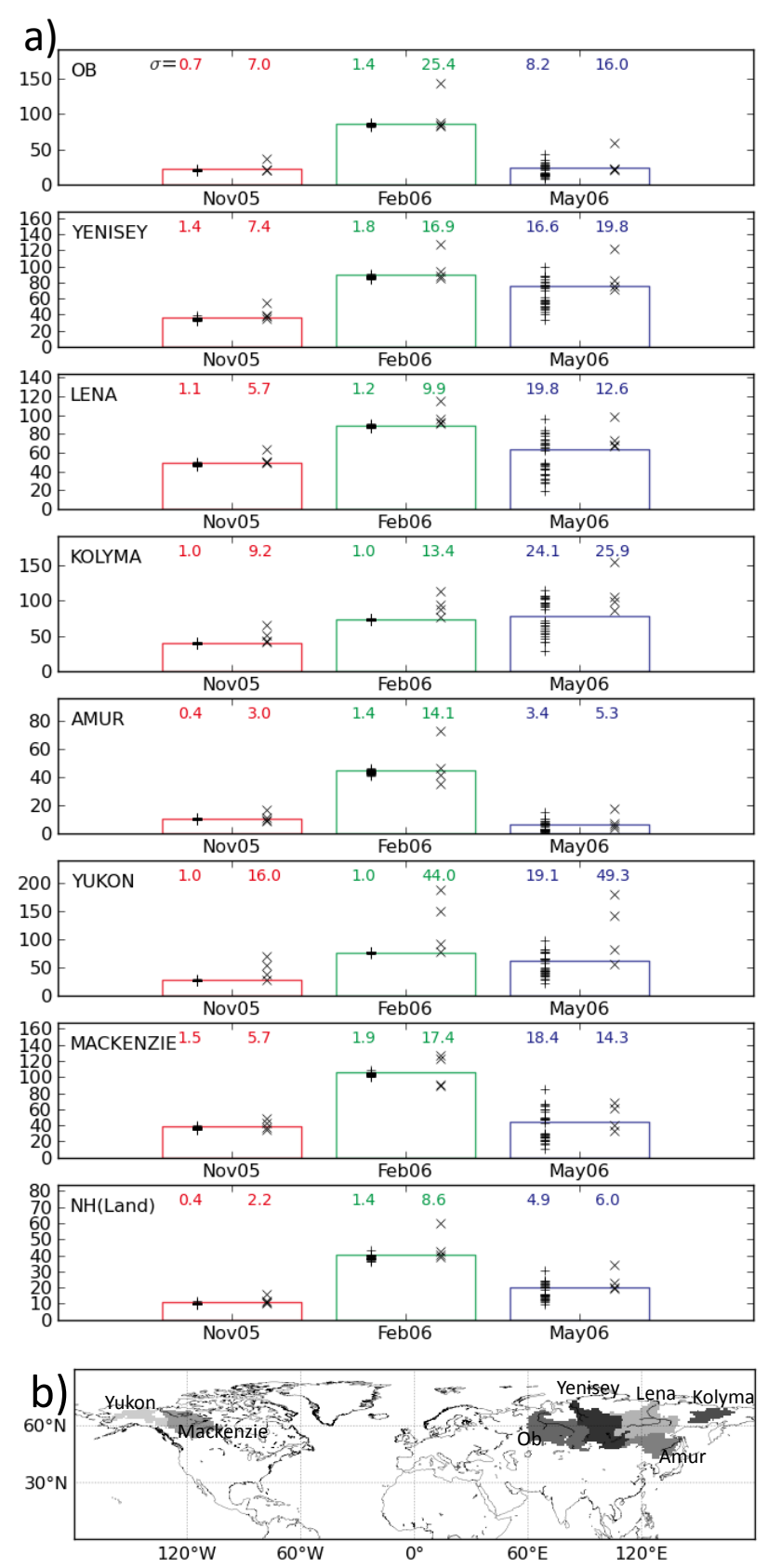

図-3 a) 北極圏流域の積雪水当量 $\left[\mathrm{kg} / \mathrm{m}^{2}\right]$. 棒グラフは標準実験 の結果で左から2005年11月（赤）2006年2月（緑）2006年5月

(青) . +のばらつきがパラメータの不確実性， $\times$ のばらつき が気象強制力の不確実性を示す．数字は，アンサンブルメン バ一の標準偏差を示している. b) 対象とした流域.

いてそれぞれについて30メンバーで2000年から2007年ま でのアンサンブル実験を行った.

\section{3. 結果}

\section{（1）北極圏流域の積雪水当量}

図-3に北極圏流域の積雪水当量の結果を示す.オビ川, エニセイ川, レナ川, コリマ川, アムール川, ユーコン 川，マッケンジー川の各流域と北半球の陸域平均につい
て，2005年11月（赤），2006年2月（緑）と5月（青）の 流域平均積雪水当量を示している．棒グラフが標準のモ デルを使った結果，＋がパラメータ摂動アンサンブル実 験の各アンサンブルメンバー，×が降水量のアンサンブ ル実験の各アンサンブルメンバー，図中の数字は標準偏 差を示している. この図を用いてパラメータ摂動アンサ ンブル実験と降水量のアンサンブル実験の比較を行うが, 性質の異なるアンサンブル実験で，アンサンブル数も異 なるため，定量的に直接比較可能な実験ではないことに 注意が必要である，それでも，結果の幅や季節による違 いを議論することは意味があるだろう。まず，2005年11 月を見ると，どの流域でもパラメータ摂動アンサンブル 実験はほぼ同じ值を取っている。一方で，降水量のアン サンブル実験はある程度ばらついている。オビ川，エニ セイ川，レナ川ではひとつの降水量を用いた実験だけ離 れた值を取り，残り4つのばらつきは小さい. ユーコン 川とマッケンジー川では比較的均等にばらつく．2月に なると，降水量のアンサンブル実験では，11月よりもば らつきが大きくなるが，パラメータ摂動アンサンブル実 験のばらつきは11月とほとんど変わらず，降水量のアン サンブル実験によるばらつきの方が大きい，5月になる と, 融雪に伴ってパラメータ摂動アンサンブル実験のば らつきが大きくなる.

\section{（2）積雪水当量の空間分布}

次に，この結果の空間分布をより詳細に検討する（図 -4） . 紙面の都合上，パラメータ摂動アンサンブル実験 による2005年11月，2006年2月，2006年5月の積雪水当量 のアンサンブル平均值と，不確実性の指標として標準偏 差について示した。2005年10月から2006年1月までは標 準偏差は比較的小さい. 例外は，北アメリカの海岸山地 で，11月から時間とともに標準偏差が大きくなっていく 2006年2月になると，ヨーロッパの一部，北緯 $40^{\circ}$ 東経 $70^{\circ}$ 付近，五大湖周辺などで標準偏差が $10 \mathrm{~kg} / \mathrm{m}^{2}$ を超え る場所が出てくる．3月には，ヨーロッパの北緯 $45^{\circ}$ 付 近，チベット高原の西側，五大湖付近で標準偏差が大き くなり，20 kg/m² を超えるところがある．4月には北緯 $60^{\circ}$ を中心ユーラシアでも北アメリカでも標準偏差が 大きくなり，5月になると標準偏差の大きい地域はさら に北上する．標準偏差の大きい場所は融雪する場所と対 応している。ほとんどの地域で融雪した6月には，ユー ラシアの東経 $90^{\circ}$ 付近，北アメリカの北部地域を除くほ とんどの地域で標準偏差は小さくなる.

\section{（3）異なるモデル間における不確実性の比較}

図-1に示したアンサンブル実験による不確実性評価の 概念図では，中央の灰色の丸が標準実験の結果を表して いる．例えば，積雪の変化を検出し原因を特定する既往 研究では，この值が解析に用いられてきた．本研究では パラメータ（第一の軸; 水色）と気象外力（第二の軸; 

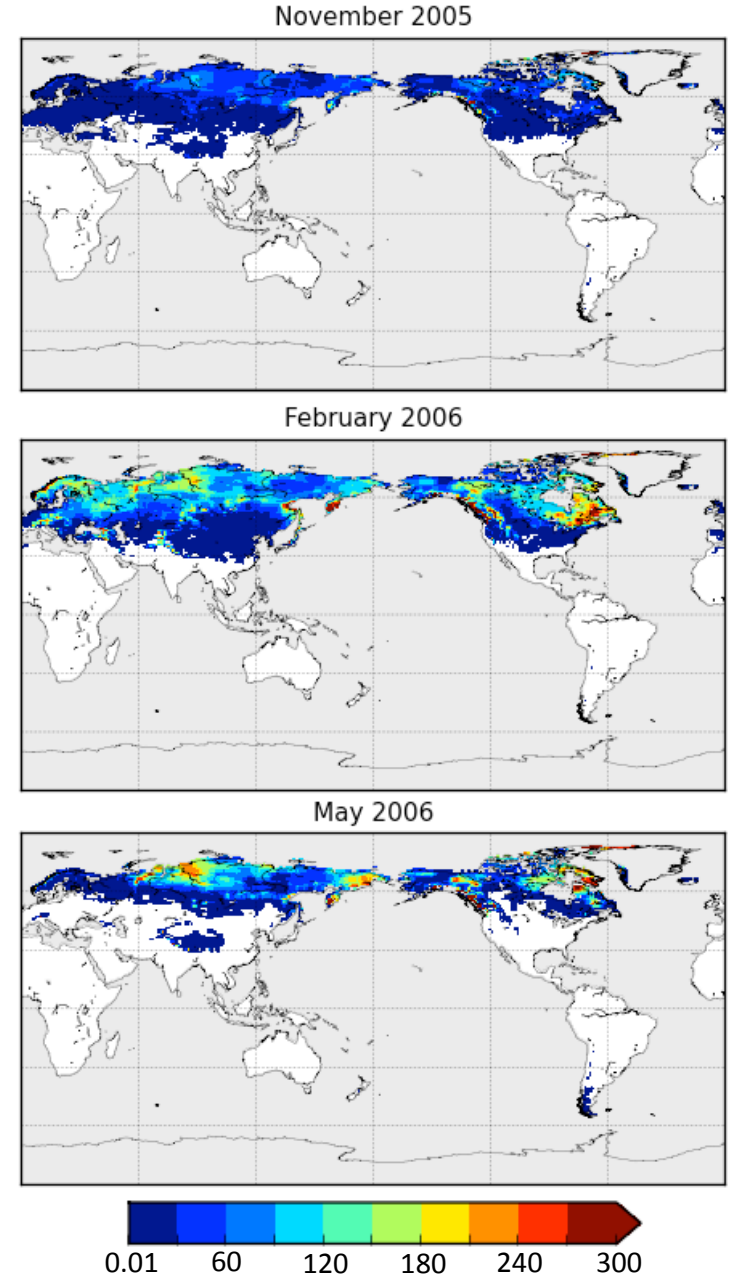

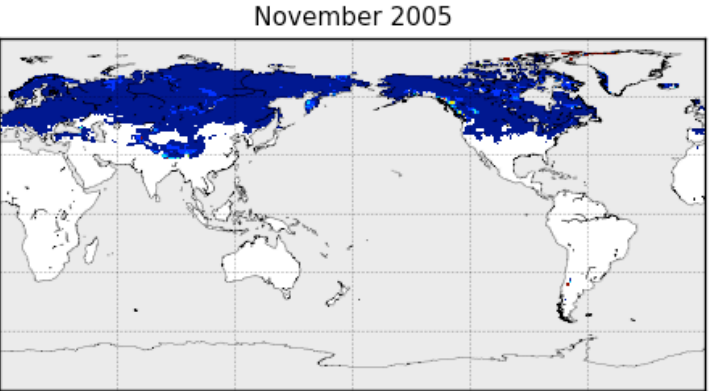

Fébruary 2006
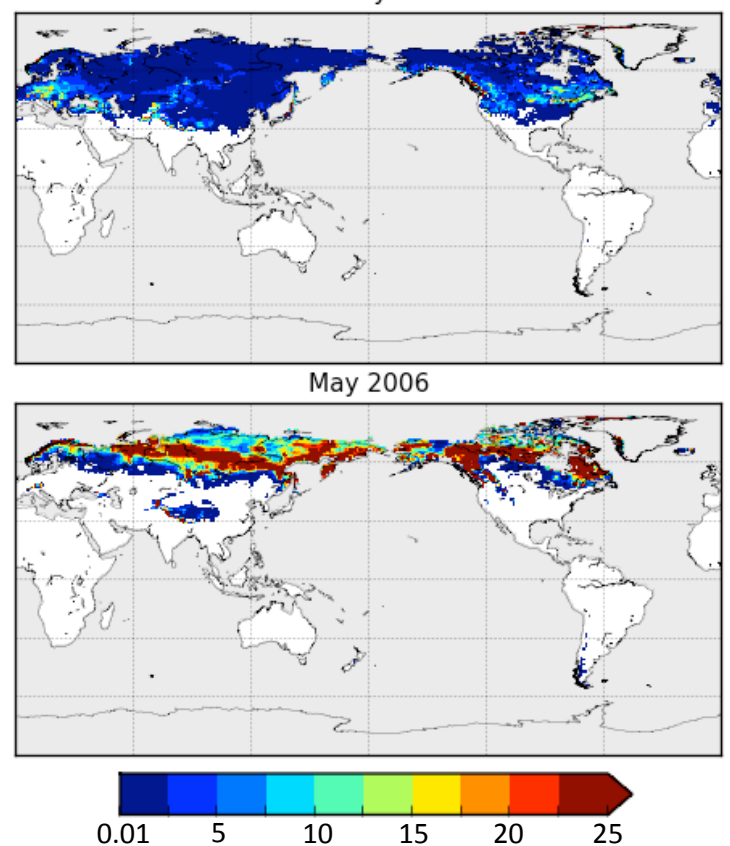

図-4 パラメータ摄動実験の結果. 2005年10月，2006年2月，2006年5月の

月平均積雪水当量のアンサンブル平均值 (左) とその標準偏差（右） $\left[\mathrm{kg} / \mathrm{m}^{2}\right]$.

緑色）のうち，全球パラメータと降水量データに関する アンサンブル実験を行い，積雪シミュレーションが各軸 に沿ってどの程度のばらつき（=不確実性）を持つのか を調ベた．ただし，アンサンブル実験は軸によって実験 設定が違うので, 軸同士の単純比較は難しい点に注意が 必要である.

モデルの複雑さによって, パラメータや降水量に起因 寸る不確実性がどの程度変化するのか調べるために，モ デル構造の異なる 3 つのモデルでパラメータに起因する 不確実性がどの程度変化するのかを調べた。図-5は, 2001年-2007年の北半球陸域平均の積雪水当量の標準偏 差について，モデル間の比較を示している.7年間の各 月について月平均を計算し，その標準偏差を示している. モデルAとモデルBを比較すると, どの季節でもモデルB の方が不確実性が大きく, 最大で $5 \mathrm{~kg} / \mathrm{m}^{2}$ 程度となってい る.これは，モデルAは積雪面積を $0 / 1$ で表現するのに対 して，モデルBは積雪被覆率が 1 となる闇值をパラメー タで決めている，そのため，似たような積雪面積になる と予想できるパラメータセットは，モデルAでは融雪に 関して似たような值をとるパラメータセットを選択して
いるのに対して，モデルBでは積雪被覆率の䦨值と融雪 に関するパラメータが相殺しているためだと考えられる. モデルBとモデルCに関しても同様のことが言える. 積雪 の少ない時期にモデルC方が大きなばらつきを示すのは, 雨雪判別のパラメータを振っているためだと考えられる.

\section{4. まとめ}

本研究ではアンサンブル実験を用いた全球積雪シミュ レーションの不確実性評価を行った. 北極圈流域の流域 平均水当量を堆積期, 積雪最大期, 融雪期で比較した結 果, 堆積期にはパラメータの不確実性は小さいこと, 降 水量に関する不確実性は比較的大きいこと，また，融雪 期になるとパラメータの不確実性は降水量の不確実性よ りも大きいか, 同程度となり, 標準実験のおよそ半分か ら1.5倍程度の值をとることがわかった。また，パラ メータに起因する不確実性をモデル間で比較した結果, 年平均積雪面積を用いる本研究の手法でパラメータを選 択すると，積雪被覆率に対して感度のあるチューニング 

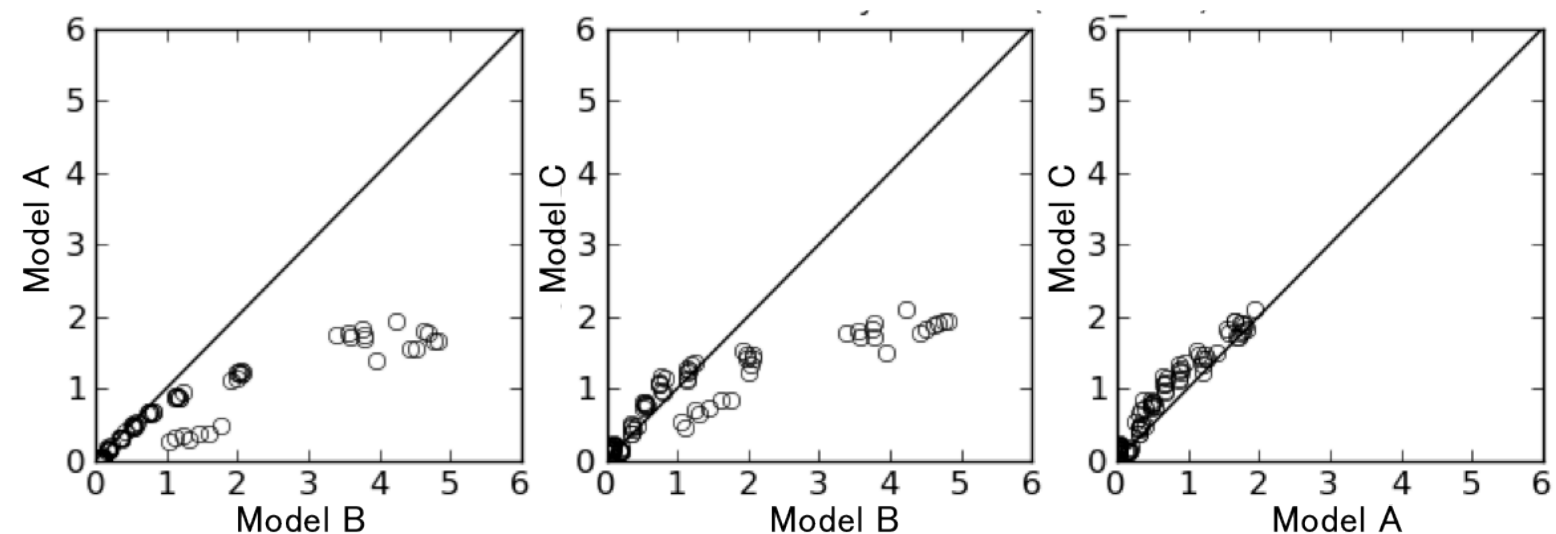

図-5 北半球陸域平均積雪水当量の標準偏差 $\left[\mathrm{kg} / \mathrm{m}^{2}\right] .2001$ 年から2007年の月平均值を用いて計算している. 左からモデルA（縦軸） とモデルB (横軸) の比較, モデルC (縦軸) とモデルB（横軸）の比較, モデルC（縱軸）とモデルA（横軸）の比較.

パラメータを持つモデルの方が，そのようなパラメータ を持たないモデルよりも不確実性は大きくなることがわ かつた.

今後の課題として，より詳細な観測（例えば，季節ご との積雪面積や，積雪被覆率の日単位のグリッドデータ） による制約を与えると，積雪水当量をどの程度制約でき るのかの検討が挙げられる．季節ごとの積雪面積につい ては，本研究の手法をそのまま適用できる可能性がある. また日単位のグリッドデータを用いるには，アンサンブ ル・カルマンフィルタといったデータ同化技術が利用で きるかもしれない．また，本研究では積雪水当量の検証 を行わなかったが，例えば現地観測の積雪深を用いて， ある地点での検証を加えることは可能だと考えられる. さらに，第 1 章で述べたような，積雪とその変化を再現 し，原因を特定するような研究において，シミュレー ション結果がいつどこで信頼できるのかといった情報を 付加することも, 本研究の今後の課題である.

謝辞：本研究はJST/CREST「持続可能な水利用を実現す る革新的な技術とシステム 安全で持続可能な水利用の ための放射性物質移流拡散シミュレータの開発」, GRENE北極気候変動研究事業，環境省環境研究総合推 進費（S-10）の成果の一部である.

\section{参考文献}

1) Lemke, P., et al.: Observations: Changes in Snow, Ice and Frozen Ground. In: Climate Change 2007: The Physical Science Basis. Cambridge University Press, Cambridge, United Kingdom and New York, NY, USA, 2007.

2) Derksen, C. and R. Brown: Spring snow cover extent reductions in the 2008-2012 period exceeding climate model projections, Geophys. Res. Lett., 2012 (in press).

3) Liston, G. E. and C. A. Hiemstra: The changing cryosphere: PanArctic snow trends (1979-2009). Journal of Climate. Vol.24, pp. 5691-5712, 2011.
4) Shi, X., P. Y. Groisman, S. J. Dery, and D. P. Lettenmaier: The role of surface energy fluxes in pan-arctic snow cover changes. Environmental Research Letters, Vol.6, 035204, 2011.

5) Rutter, N., R. Essery, et al.: Evaluation of forest snow processes models (SnowMIP2). J. Geophys. Res., Vol.114, 2009.

6) Slater, A. G., et al.: The representation of snow in land surface schemes: Results from PILPS 2(d), Journal of Hydrometeorology, Vol.2, pp.7-25, 2001.

7) Essery, R. and P. Etchevers: Parameter sensitivity in simulations of snowmelt, J. Geophys. Res., Vol.109, 2004.

8) He, M., T. S. Hogue, et al.: Characterizing parameter sensitivity and uncertainty for a snow model across hydroclimatic regimes., Advances in Water Resources, Vol.34, pp.114-127, 2011.

9) Shiogama, H., M. Watanabe et al.: Perturbed Physics Ensemble using the MIROC5 Coupled Atmosphere-Ocean GCM without Flux Corrections: Experimental Design and Results, Climate Dynamics, 2012 (in review).

10) Watanabe, M., H. Shiogama, et al.: Using a Multiphysics Ensemble for Exploring Diversity in Cloud-Shortwave Feedback in GCMs, Journal of Climate, Vol.25 pp.5416-5431, 2012.

11) Takata, K., S. Emori, and T. Watanabe: Development of the minimal advanced treatments of surface interaction and runoff, Global and Planetary Change, Vol.38, pp.209-222, 2003.

12) Kim, H., P. J. F. Yeh, T. Oki, and S. Kanae: Role of rivers in the seasonal variations of terrestrial water storage over global basins, Geophys. Res. Lett., Vol.36, L17402, 2009.

13) McKay, M., R. Beckman, and W. Conover: A comparison of three methods for selecting values of input variables in the analysis of output from a computer code, Technometrics, Vol. 21, pp. 239-245, 1979.

14) Hall, D., V. Salomonson, G. Riggs: MODIS Terra/Aqua Snow Cover Monthly L3 Global 0.05Deg CMG, Version 5. Version 5.0. Boulder, CO, USA, National Snow and Ice Data Center., 2006.

15) Liston, G. E.: Representing Subgrid Snow Cover Heterogeneities in Regional and Global Models, Journal of Climate, Vol.17, pp.13811397, 2004

(2012. 9. 30受付) 